\title{
CONVERSION OF (+)-DIHYDROQUERCETIN TO (+)-2,3-trans-3,4-cis-LEUCOCYANIDIN AND (+)-CATECHIN WITH AN ENZYME EXTRACT FROM MATURING GRAINS OF BARLEY
}

\author{
by \\ KLAUS NYEGAARD KRISTIANSEN \\ Department of Physiology, Carlsberg Laboratory, \\ Gamle Carlsberg Vej 10, DK-2500 Copenhagen Valby
}

\begin{abstract}
Keywords: Procyanidin biosynthesis, reductases, leucocyanidin epimerization, high pressure liquid chromatography, 'H NMR
\end{abstract}

\begin{abstract}
A soluble, NADPH-dependent reductase, catalyzing the reduction of (+)-dihydroquercetin to (+)-2,3-trans-3,4cis-leucocyanidin ((2R,3S,4S)-3,4,5,7,3',4'-hexahydroxyflavan), was demonstrated in an enzyme preparation from maturing grains of wild type barley (Hordeum vulgare L., cv. Nordal). This reductase activity had a pH-optimum around 7.0 and was strongly inhibited by the product of the reaction. Furthermore, a second, less active NADPH-dependent reductase, catalyzing the reduction of $(+)-2,3-$ trans-3,4-cis-leucocyanidin to (+)-catechin, was demonstrated by a double step reduction of (+)-dihydroquercetin to (+)-catechin.

The reaction product of $(+)$-dihydroquercetin reductase was identified by co-chromatography with an authentic standard of (+)-2,3-trans-3,4-cis-leucocyanidin, which was prepared chemically by acid epimerization of (+)-2,3-trans-3,4-trans-leucocyanidin $\left((2 R, 3 S, 4 R)-3,4,5,7,3\right.$ ', $4^{\prime}$-hexahydroxyflavan) and characterized by ' $H$ NMR spectroscopy in the free phenolic form.
\end{abstract}

\section{INTRODUCTION}

In a previous study on the biosynthesis of procyanidins in maturing barley grains (9), the in vivo incorporation of $(+)-\left({ }^{14} \mathrm{C}\right)$ dihydroquercetin into (+)-2,3-trans-3,4-cis-leucocyanidin ((2R,3S,4S)-3,4,5,7,3',4'-hexahydroxyflavan), (+)-catechin, procyanidin B3, and procyanidin $\mathrm{C} 2$ was demonstrated. The proposed biosynthetic pathway for the conversion of $(+)$-dihydroquercetin to procyanidin C2 involved four enzyme activities. Recently, two reductases acting in sequence to reduce ( + -dihydroquercetin to $(+)-2,3-$ trans-3,4-cis-leucocyanidin and then the leucocyanidin to $(+)$-catechin have been reported by STAFFORD and co-workers $(12,13$, 15 ) in extracts of cell cultures of Douglas fir needles.

In the present study two analogous enzyme activities are identified in an extract from maturing barley grains. Furthermore, a standard of (+)-2,3-trans-3,4-cis-leucocyanidin is prepared and characterized by ${ }^{1} \mathrm{H}$ NMR.

Abbreviations: $D H Q=$ dihydroquercetin; ${ }^{1} H$ NMR = proton nuclear magnetic resonance; $H P L C=$ high pressure liquid chromatography; TLC = thin layer chromatography; Tris = 2-amino-2-(hydroxymethyl)-1,3-propanediol. 


\section{MATERIALS AND METHODS}

\subsection{Plant material}

Plants of wild type barley (Hordeum vulgare L., cv. Nordal) were grown in a growth chamber as described previously (9).

\subsection{Chemicals}

(+)-(2R,3R)-(4a,5,6,7,8,8a- $\left.{ }^{14} \mathrm{C}\right)$-Dihydroquercetin $\left(4.2 \mathrm{mCi} \cdot \mathrm{mmol}^{-1}\right)$ was synthesized as described previously (9) and unlabelled (+)-dihydroquercetin was purchased from Serva(Heidelberg, West Germany). (+)-2,3-trans-3,4-transLeucocyanidin ((2R,3S,4R)-3,4,5,7,3',4'-hexahydroxyflavan) was prepared by the method of PORTER and FOO (11), and as previously, identified by 'H NMR and mass spectroscopy (9). Procyanidin B3 ( + )-catechin- $(4 \alpha \rightarrow 8)-(+)$-catechin) was synthesized according to DELCOUR et al. (6). (+)-Catechin and glucose-6-phosphate dehydrogenase were obtained from Fluka AG (Buchs, Switzerland). NADH, NADPH, and glucose-6-phosphate were from Sigma (St. Louis, USA). Sephadex G-25 came from Pharmacia (Uppsala, Sweden), and Dowex $1 \mathrm{X} 2$ and protein assay reagent were supplied by Bio-Rad (Richmond, USA). All other reagents were of analytical grade.

\subsection{Chromatography}

\subsubsection{High pressure liquid chromatography} (HPLC)

Three HPLC systems were used for separation of flavonoids:

I. A $\mu$ Bondapak $\mathrm{C}_{18}$ column, $30 \mathrm{~cm} \times 3.9 \mathrm{~mm}$ (Waters Assoc.) eluted with a linear gradient from $2-10 \%$ acetic acid in $30 \mathrm{~min}$. The flowrate was $2 \mathrm{ml}-\mathrm{min}^{-3}$.

II. A $\mu$ Bondapak phenyl column, $30 \mathrm{~cm} \times 3.9$ $\mathrm{mm}$ (Waters Assoc.) eluted isocratically with water. The flowrate was $1-2 \mathrm{ml} \cdot \mathrm{min}^{-1}$.

III. A Nova-Pak $\mathrm{C}_{18}$ column, $15 \mathrm{~cm} \times 3.9 \mathrm{~mm}$ (Waters Assoc.) eluted with a linear gradient from $2-10 \%$ acetic acid in $15 \mathrm{~min}$ and maintained at $10 \%$ acetic acid for $10 \mathrm{~min}$. The flowrate was $1 \mathrm{ml} \cdot \mathrm{min}^{-1}$.

The chromatography was carried out at $20^{\circ} \mathrm{C}$. Elution was monitored spectrophotometrically at $280 \mathrm{~nm}$ and concentrations of flavonoids were calculated from peak areas. Relevant elution volumes are given in Table I. ${ }^{14} \mathrm{C}$-labelled compounds were detected and quantified using a Berthold (Wildbad, West Germany) HPLC radioactivity monitor LB505, equipped with a GT200 measuring cell ( $200 \mu 1$ glass scintillator, efficiency 36.3\%), in connection with Berthold radiochromatography data system LB500M (Radio-HPLC).

\subsubsection{Thin layer chromatography (TLC)}

Separations were performed on Merck (Darmstadt, West Germany) precoated cellulose $F_{254}$ plates $(0.1 \mathrm{~mm})$ developed in: 1$)$ n-butanol:water $(7: 2, v / v)$, or 2$)$ water saturated s-butanol. Relevant $R_{f}$ values are given in Table $I$. Flavanols were visualized by spraying with a $4: 1$ $(\mathrm{v} / \mathrm{v})$ mixture of $5 \%(\mathrm{w} / \mathrm{v})$ vanillin in ethanol and conc. $\mathrm{HCl}(10)$. Radioactive compounds were localized by scanning the plates using a Packard model 7201 radiochromatogram scanner.

\subsection{Chemical synthesis of (+)-2,3-trans $-3,4-$ cis-leucocyanidin}

(+)-2,3-trans-3,4-cis-Leucocyanidin was prepared from the (+)-2,3-trans-3,4-trans isomer by acid epimerization at the $\mathrm{C}-4$ position. $\mathrm{A}$ sample of $52 \mathrm{mg} \mathrm{3,4-trans-leucocyanidin} \mathrm{in} 1 \mathrm{ml}$ acetone was treated with $100 \mathrm{ml} 0.1 \%(\mathrm{v} / \mathrm{v})$ acetic acid (pH 3.2) for $100 \mathrm{~min}$ at $40{ }^{\circ} \mathrm{C}$, resulting in a mixture of the 3,4-cis and 3,4-trans isomers in a ratio of $3: 2$. The mixture was immediately frozen in liquid $\mathrm{N}_{2}$ and freezedried. Recoveries of leucocyanidins greater than $95 \%$ were obtained in this way. The yellowish powder was then dissolved in $1 \mathrm{ml}$ methanol and the 3,4-cis isomer was purified by HPLC using system II (section 2.3.1). Approximately 100\% of the collected leucocyanidin was recovered after freeze-drying the eluates. A total of $21 \mathrm{mg}$ was isolated as a white powder.

A 'HNMR spectrum of 3,4-cis-leucocyanidin in $\mathrm{d}_{6}$-acetone $(6 \mathrm{mg} / 0.5 \mathrm{ml})$ was recorded on a Bruker AM500 spectrometer (500 MHz) with acetone as internal standard.

\subsection{Preparation of crude enzyme extract}

Awnless developing barley grains $(1.25 \mathrm{~g}$, approx. 12 days old) were frozen in liquid $\mathrm{N}_{2}$ and 
Table I. Elution volumes on HPLC and $R_{\text {q }}$ values on TLC of relevant flavonoids. The chromatographic systems (I-III, 1-2) are detailed in section 2.3 .

\begin{tabular}{|c|c|c|c|c|c|}
\hline \multirow{2}{*}{ Compound } & \multicolumn{3}{|c|}{ Elution volume (ml) } & \multicolumn{2}{|c|}{$R_{f}$ value } \\
\hline & I & II & III & 1 & 2 \\
\hline $\begin{array}{l}\text { (+)-2,3-trans-3,4-cis } \\
\text { Leucocyanidin }\end{array}$ & 14.5 & 29.2 & 8.2 & 0.46 & 0.60 \\
\hline $\begin{array}{l}(+)-2,3-\text { trans-3,4-trans- } \\
\text { Leucocyanidin }\end{array}$ & 22.2 & 53.8 & 11.6 & 0.59 & 0.71 \\
\hline$(+)$-Catechin & - & 71.0 & 12.3 & 0.69 & 0.80 \\
\hline (+)-Dihydroquercetin & - & - & 22.0 & - & - \\
\hline Procyanidin B3 & - & - & 10.0 & - & - \\
\hline
\end{tabular}

homogenized in a mortar together with $1.25 \mathrm{~g}$ glass beads $(250-300 \mu \mathrm{m})$. The homogenate was suspended in $2.5 \mathrm{ml} 0.1 \mathrm{M}$-Tris- $\mathrm{HCl}$ buffer $(\mathrm{pH}$ 7.5) containing $2 \mathrm{mM}-1$,4-dithiothreitol and $10 \%(\mathrm{v} / \mathrm{v})$ glycerol, squeezed through nylon mesh and then centrifuged for $15 \mathrm{~min}$ at $20,000 \times \mathrm{g}$. The supernatant was stirred for 30 min with $10 \%(w / v)$ Dowex 1 X2 which had previously been equilibrated with the extraction buffer, then filtered through nylon mesh and centrifuged for $15 \mathrm{~min}$ at $20,000 \times \mathrm{g}$. The supernatant was desalted on a Sephadex G-25 column $(5 \times 1.6 \mathrm{~cm})$, equilibrated and eluted with

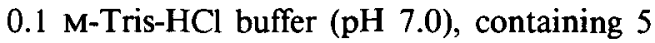
mM-sodium ascorbate and $10 \%(\mathrm{v} / \mathrm{v})$ glycerol. The protein peak eluting at the void volume was used as the enzyme source (4.9 mg protein in 3.5 $\mathrm{ml}$ ). All steps were carried out at $0-4{ }^{\circ} \mathrm{C}$.

\subsection{Standard enzyme assay}

The assay system contained in a total volume of $200 \mu \mathrm{l}: 20 \mu \mathrm{mol}$ Tris- $\mathrm{HCl}$ buffer ( $\mathrm{pH} \mathrm{7.0)}$ ), $\mu$ mol sodium ascorbate, $20 \mu$ glycerol, 10.7 nmol $\left({ }^{14} \mathrm{C}\right)$ dihydroquercetin $\left(10^{5} \mathrm{dpm}\right), 400$ nmol NADPH, and crude enzyme extract $(28 \mu \mathrm{g}$ protein). Incubation was carried out for $30 \mathrm{~min}$ at $30^{\circ} \mathrm{C}$. Four $\mu \mathrm{g}$ each of 3,4-cis-leucocyanidin, catechin, and procyanidin B3 in $5 \mu$ methanol were then added as carriers, and the mixture was immediately extracted with ethyl acetate $(3 \times$ $500 \mu \mathrm{l})$. The combined extracts were evaporated to dryness under a stream of $\mathrm{N}_{2}$ at room tempe- rature. The residue was dissolved in $100 \mu l$ water, and the products were separated and quantified by subjecting an aliquot to radio-HPLC using system III (section 2.3 .1 ). Generally $85-95 \%$ of the starting radioactivity was recovered in residual dihydroquercetin and reaction products, whereas up to $10 \%$ remained in the water phase after the ethyl acetate extractions.

\subsection{Identification of reaction products}

Radioactive peaks corresponding to 3,4-cisleucocyanidin and catechin were purified by HPLC (system III, section 2.3.1), immediately frozen in liquid $\mathrm{N}_{2}$ and freeze-dried. The compounds were dissolved in methanol and identified by co-chromatography of radioactivity with authentic samples, using HPLC system II and TLC systems 1 and 2 (section 2.3).

\subsection{Determination of pH-optimum of dihydroquercetin reductase activity}

After the Dowex 1X2 treatment (section 2.5) aliquots of the crude enzyme extract were desalted on Sephadex G-25 columns $(5 \times 1.6 \mathrm{~cm})$, equilibrated and eluted with buffers ranging in $\mathrm{pH}$ from 4.5 to 9.0 . Enzyme assays were performed as described in section 2.6, except that incubations were carried out in buffers of 0.126 M-sodium phosphate, 0.037 M-sodium citrate for extracts eluted between $\mathrm{pH} 4.5$ and 7.0, and in buffers of $0.1 \mathrm{M}$-Tris- $\mathrm{HCl}$ for extracts eluted 


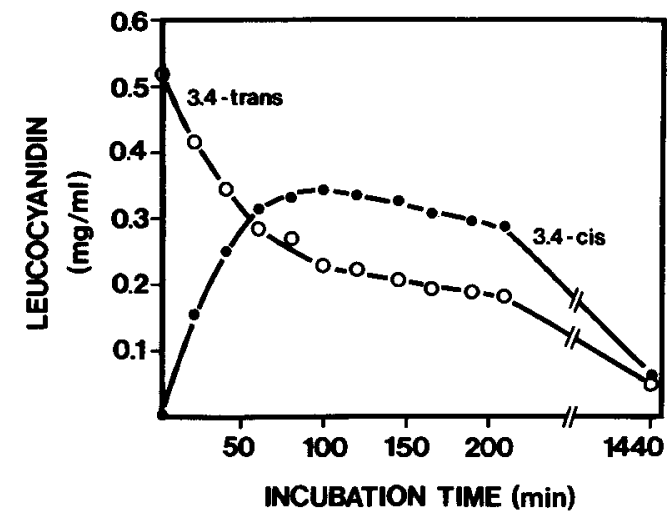

Figure 1. Time course of epimerization of $(t)-2,3-$ trans - 3,4-trans-leucocyanidin $\left(0.52 \mathrm{mg} \cdot \mathrm{ml}^{-1}\right)$ to (+)2,3-trans-3,4-cis-leucocyanidin in $0.1 \%(\mathrm{v} / \mathrm{v})$ acetic acid ( $\mathrm{pH} \mathrm{3.2)}$ at $40^{\circ} \mathrm{C}$. At the times indicated an aliquot of the reaction mixture was analyzed by HPLC using system I (section 2.3.1) to determine the concentrations of leucocyanidins.

between $\mathrm{pH} 7.0$ and 9.0. All buffers contained 5 mM-sodium ascorbate and $10 \%(v / v)$ glycerol.

\subsection{Determination of protein}

Protein was determined by the method of BRADFORD (5) using the Bio-Rad protein reagent and bovine serum albumin as standard protein.

\section{RESULTS}

\subsection{Synthesis and identification of (+)-2,3- trans-3,4-cis-leucocyanidin}

That flavan-4-ols epimerize at the $\mathrm{C}-4$ position to give a mixture of the pseudo-axial and pseudo-equatorial compounds (3) permits synthesis of (+)-2,3-trans-3,4-cis-leucocyanidin from the pseudo-equatorial epimer, $(+)-2,3-$ trans-3,4-trans-leucocyanidin. A time course study of the epimerization of the 3,4-trans-leucocyanidin is shown in Figure 1. A maximum yield of $60 \% 3,4-c i s$-leucocyanidin was obtained after incubation for approximately $100 \mathrm{~min}$ where the relative concentration of the 3,4-cis to the 3,4-trans isomer was 3:2. This ratio remained constant for at least another $100 \mathrm{~min}$,

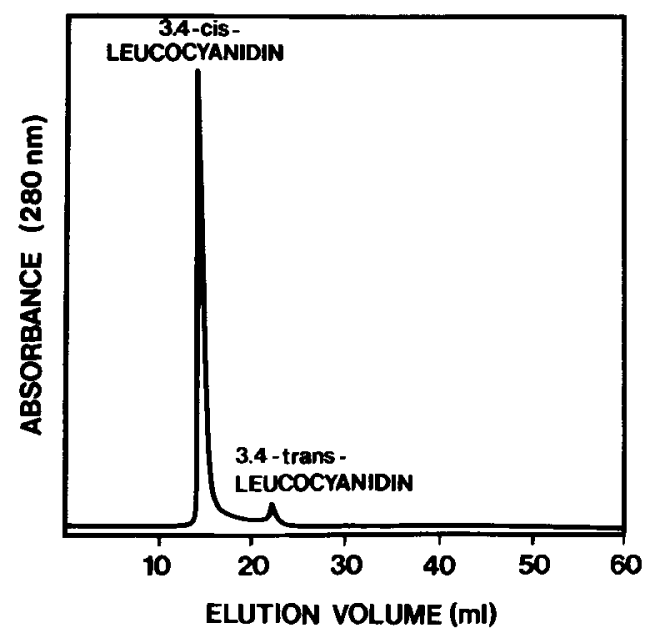

Figure 2. High pressure liquid chromatogram of the final (+)-2,3-trans-3,4-cis-leucocyanidin preparation. HPLC system I (section 2.3.1) was used.

but the concentrations of the individual leucocyanidins decreased linearly with time due to polymerization. Thus, in the present case the 4-pseudo-axial product, i.e., the 3,4-cis isomer, predominated. By contrast STAFFORD et al. (13, 15) observed a $1: 2$ ratio of the 3,4-cis to the 3,4-trans isomer when epimerization was carried out in a citrate-phosphate buffer ( $\mathrm{pH} 2.6)$ at $40^{\circ} \mathrm{C}$.

For larger scale preparation of 3,4-cis-leucocyanidin, epimerization was stopped after 100 min by freezing the mixture in liquid $\mathrm{N}_{2}$. The final preparation obtained after purification by HPLC using system II (section 2.3.1) contained less than $3 \%$ of the 3,4-trans isomer (Figure 2), and TLC analyses using systems 1 and 2 (section 2.3.2) revealed vanillin staining bands corresponding only to the two leucocyanidins.

The structure of (+)-2,3-trans-3,4-cis-leucocyanidin was confirmed by 'H NMR spectroscopy. The spectrum (Figure 3) showed the following characteristic chemical shifts and couplings: $\delta 3.26$ (dd, $\mathrm{H}-3, \mathrm{~J}=3.6$ and $9.0 \mathrm{~Hz}$ ), $4.51(\mathrm{~d}, \mathrm{H}-2, \mathrm{~J}=9.3 \mathrm{~Hz}), 4.55(\mathrm{~d}, \mathrm{H}-4, \mathrm{~J}=3.7$ $\mathrm{Hz}), 5.78(\mathrm{~d}, \mathrm{H}-6, \mathrm{~J}=1.4 \mathrm{~Hz}), 6.00(\mathrm{~d}, \mathrm{H}-8, \mathrm{~J}=$ $1.4 \mathrm{~Hz}$ ), 6.98 (d, H-5', J = 1.1 Hz), 7.00 (s, H-2'), and $7.16(\mathrm{~d}, \mathrm{H}-6, \mathrm{~J}=1.1 \mathrm{~Hz})$. The couplings 


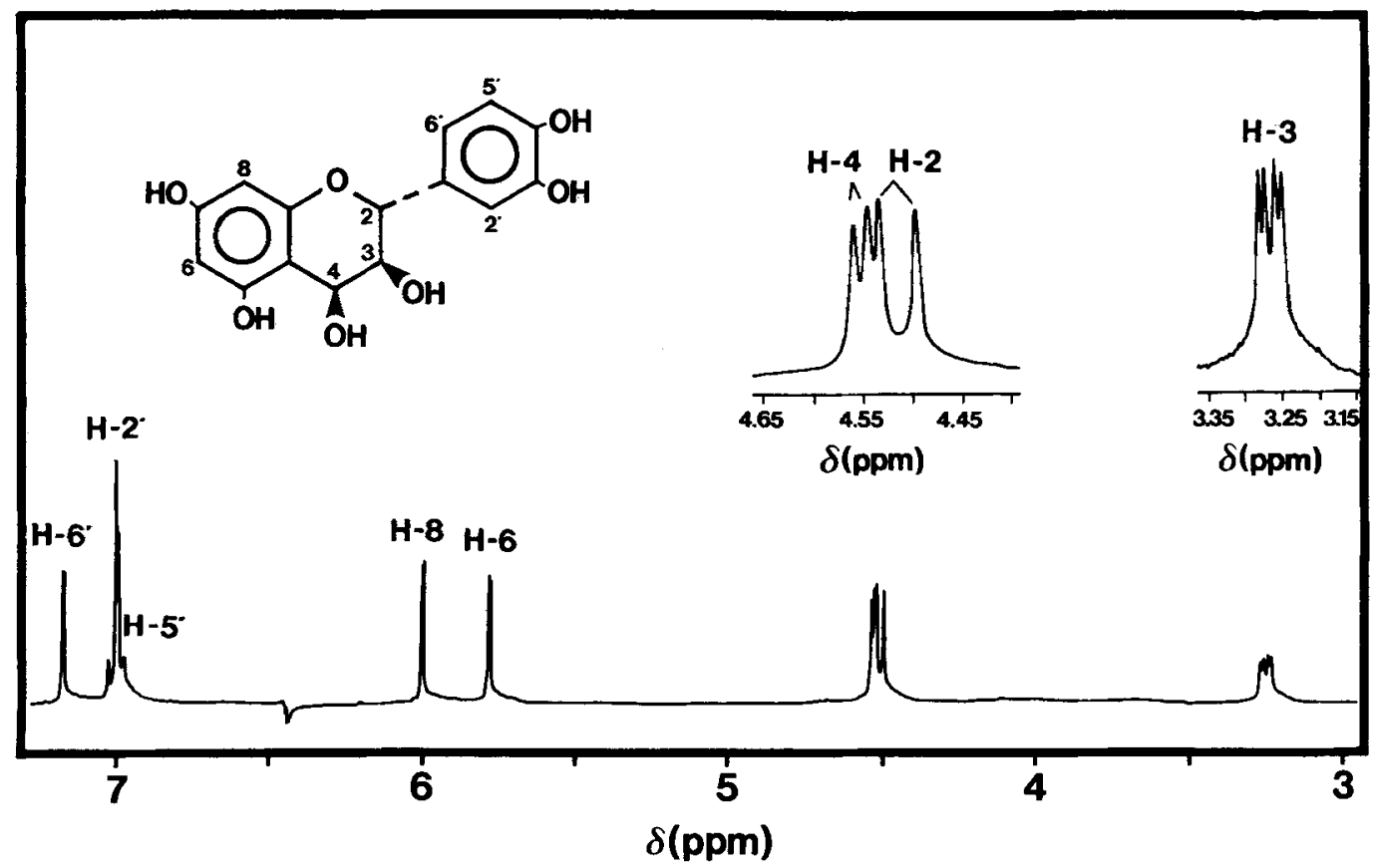

Figure 3. $500 \mathrm{MHz}{ }^{\prime} \mathrm{H}$ NMR spectrum of (+)-2,3-trans-3,4-cis-leucocyanidin in $\mathrm{d}_{6}$-acetone at $20^{\circ} \mathrm{C}$. Acetone was used as internal standard. The inserts are expanded resonances of $\mathrm{H}-3, \mathrm{H}-2$ and $\mathrm{H}-4$.

between $\mathrm{H}-2$ and $\mathrm{H}-3\left(\mathrm{~J}_{2,3}=9.3 \mathrm{~Hz}\right)$ and between $\mathrm{H}-3$ and $\mathrm{H}-4\left(\mathrm{~J}_{3,4}=3.7 \mathrm{~Hz}\right)$ are in agreement with a 2,3-trans-3,4-cis configuration (4). Coupling constants of $\mathrm{J}_{2,3}=10.0 \mathrm{~Hz}$ and $\mathrm{J}_{3,4}=7.8 \mathrm{~Hz}$ were previously obtained for the (+)-2,3-trans-3,4trans isomer (9).

The absorption spectrum of 3,4-cis-leucocyanidin (Figure 4) showed a maximum at $278 \mathrm{~nm}$. At this wavelength $\log \varepsilon$ was 3.53 which is identical to the value obtained by PORTER and Foo (11) for the 3,4-trans isomer.

After reduction of dihydroquercetin with $\mathrm{NaBH}_{4}$, the resulting product, (+)-2,3-trans-3,4trans-leucocyanidin, is accompanied by a minor leucocyanidin isomer. The latter was previously isolated by LH- 20 chromatography and HPLC, and tentatively identified as (+)-2,3-trans-3,4cis-leucocyanidin on the basis of various indirect methods (9). This structure has now been confirmed by co-chromatography of the compound with the standard prepared in the present study.

\subsection{Enzymatic reduction of (+)-dihydro- quercetin}

The crude enzyme extracts of maturing barley grains were prepared from grains harvested approximately 12 days after flowering where maximal catechin and procyanidin synthesis occur (9). When the enzyme preparation was incubated with $(+)-\left({ }^{14} \mathrm{C}\right)$ dihydroquercetin in the presence of NADPH, a new radioactive compound which co-migrated with 3,4-cis-leucocyanidin was observed by radio-HPLC analysis of the ethyl acetate soluble compounds (Figure $5 \mathrm{~A})$. This product was not formed when a boiled enzyme preparation was used (Figure 5B): The identity of the compound as (+)-2,3-trans-3,4cis-leucocyanidin was unequivocally established, after purification of the labelled product by HPLC, by co-migration of the radioactivity with the authentic sample (section 3.1) in various chromatographic systems (section 2.7).

The formation of 3,4-cis-leucocyanidin showed an absolute requirement for reducing 


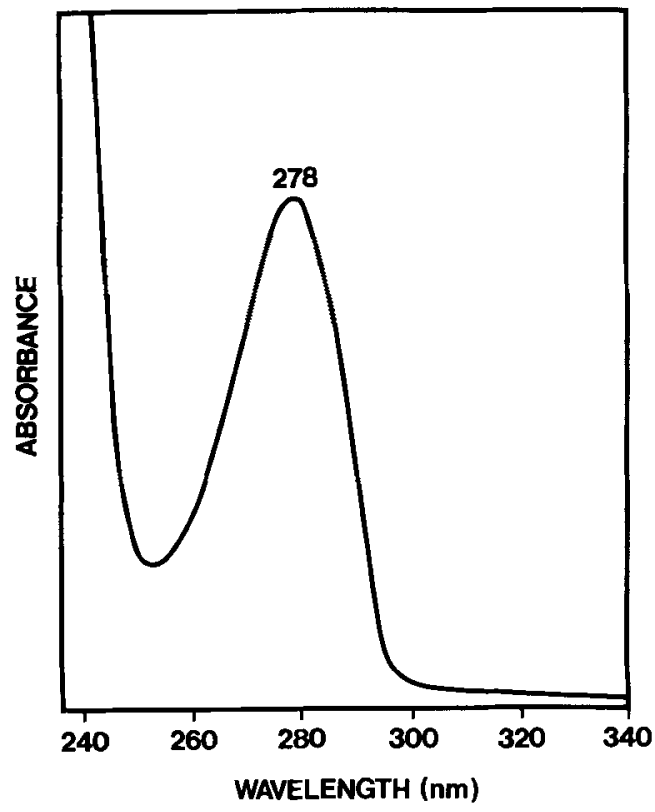

Figure 4. Absorption spectrum of $(+)-2,3-$ trans-3,4cis-leucocyanidin in $50 \%(\mathrm{v} / \mathrm{v})$ aqueous methanol.

equivalents (Table II). The dihydroquercetin reductase activity was dependent on NADPH but fairly high activities were obtained with NADH. The activities with 1,2 , and $5 \mathrm{~mm}$ NADH were 25,65 , and $88 \%$, respectively, of those observed with NADPH at the same concentration. NADH in the presence of NADPH slightly reduced the activity.

After preparation of the microsomal fraction by centrifugation of the crude extract at 100,000 $\times \mathrm{g}$ for $30 \mathrm{~min}$, the dihydroquercetin reductase activity remained in the supernatant (Table II).

The reduction of dihydroquercetin had a pH-optimum around 7.0 but a local optimum around 6.0 (Figure 6). Under standard assay conditions the formation of 3,4-cis-leucocyanidin was linear with protein concentration up to about $45 \mu \mathrm{g}$ per assay (Figure 7), and with time for about $35 \mathrm{~min}$ (Figure 8 ). The decrease in synthesis occurring after $35 \mathrm{~min}$ was not due to depletion of NADPH since addition of a NADPH-regenerating system, consisting of 5 mM-glucose-6-phosphate and 1 unit glucose-6phosphate dehydrogenase, to the assay mixture did not prolong the linear phase. The maximal

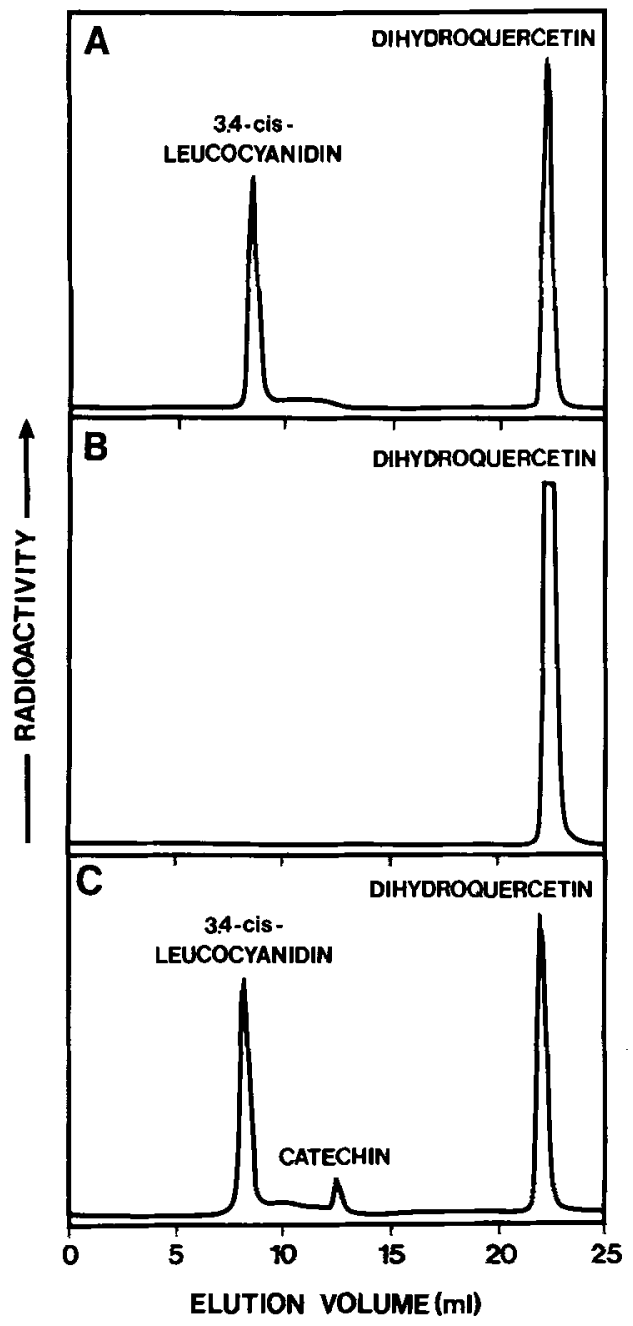

Figure 5. Radio-high pressure liquid chromatograms of ethyl acetate extracts from incubations of crude enzyme extracts with $(+)-\left({ }^{14} \mathrm{C}\right)$ dihydroquercetin in the presence of NADPH for $30 \mathrm{~min}$ at $30^{\circ} \mathrm{C}$, using in the assay (A) $28 \mu \mathrm{g}$ protein, (B) $28 \mu \mathrm{g}$ protein that had been boiled for $5 \mathrm{~min}$ at $100{ }^{\circ} \mathrm{C}$, and (C) $252 \mu \mathrm{g}$ protein. HPLC system III (section 2.3.1) was used.

activity in the crude enzyme extract was 60 $\mu \mathrm{kat} \cdot \mathrm{kg}^{-1}$.

When the crude enzyme preparation was incubated with $\left({ }^{14} \mathrm{C}\right)$ dihydroquercetin in the presence of NADPH for longer periods than the standard $30 \mathrm{~min}$, or when using higher protein concentrations than the standard $28 \mu \mathrm{g}$, a minor new radioactive compound which co-migrated 
Table II. Cofactor requirement of (+)-dihydroquercetin (DHQ) reductase activity and localization of activity after ultracentrifugation.

\begin{tabular}{lllc}
\hline Enzyme source & $\begin{array}{l}\text { Cofactor } \\
\text { added }\end{array}$ & $\begin{array}{l}\text { Concentration, } \\
\text { mM }\end{array}$ & $\begin{array}{l}\text { Relative DHQ } \\
\text { reductase activity }{ }^{2}, \%\end{array}$ \\
\hline Crude extract & None & 0 \\
& NADPH & 1 & 76 \\
& & 2 & 100 \\
& NADH & 5 & 102 \\
& & 1 & 19 \\
& 2 & 65 \\
& NADPH & 5 & 90 \\
$100,000 \times \mathrm{g}$ & NADH & 2 & 94 \\
supernatant & 2 & 100 \\
$100,000 \times \mathrm{g}$ & NADPH & 2 & 0 \\
pellet & NADPH & 2 & \\
\hline $100 \%$ corresponds to incorporation of 29,000 dpm into 3,4-cis-leucocyanidin under standard conditions (section \\
2.6)$.
\end{tabular}

with catechin, was observed upon radio-HPLC analysis (Figure $5 \mathrm{C}$ ). The identity of the minor product as $(+)$-catechin was unequivocally established by co-migration of the radioactivity with an authentic standard in various chromato- graphic systems (section 2.7). The formation of catechin was linear with protein concentration up to at least $252 \mu \mathrm{g}$ (Figure 7), and with time for at least $180 \mathrm{~min}$ (Figure 8) under standard conditions. Catechin formation required

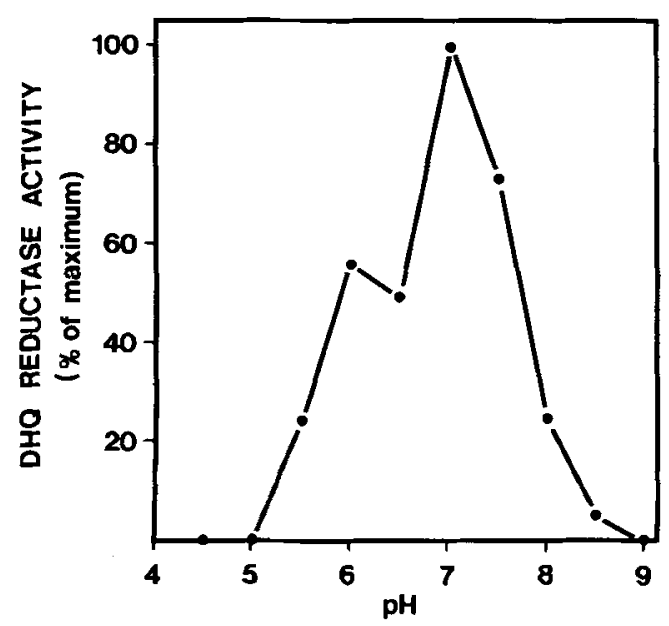

Figure 6. Effect of $\mathrm{pH}$ of incubation mixture on dihydroquercetin (DHQ) reductase activity (see section 2.8).

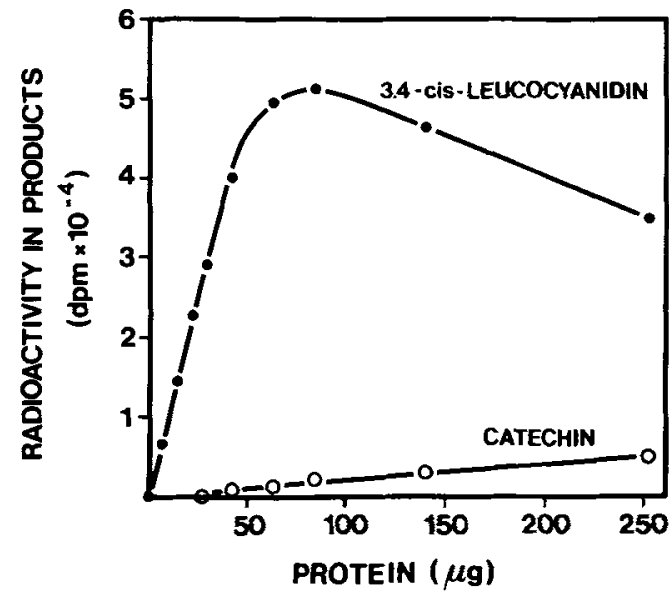

Figure 7. Effect of protein concentration on incorporation of radioactivity from $(+)-\left({ }^{14} \mathrm{C}\right)$ dihydroquercetin into (+)-2,3-trans-3,4-cis-leucocyanidin and (+)-catechin under standard enzyme assay conditions (section 2.6). $1 \mathrm{nmol}=9324 \mathrm{dpm}$. 


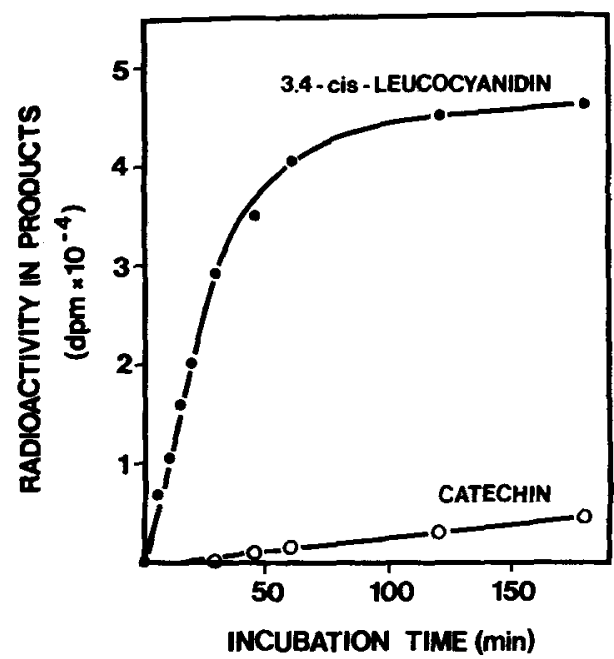

Figure 8. Time course of incorporation of radioactivity from $(+)-\left({ }^{14} \mathrm{C}\right)$ dihydroquercetin into $(+)-2,3-$ trans $-3,4-$ cis-leucocyanidin and $(+)$-catechin by a crude enzyme extract under standard conditions (section 2.6). $1 \mathrm{nmol}$ $=9324 \mathrm{dpm}$.

NADPH. No synthesis could be detected when 2 mM-NADH was substituted for $2 \mathrm{~mm}$ NADPH even though 3,4-cis-leucocyanidin is formed. The synthesis of catechin was not stimulated in the presence of $2 \mathrm{mM}$ each of NADPH and NADH. The maximal activity in the crude enzyme extract was $1.5 \mu \mathrm{kat} \cdot \mathrm{kg}^{-1}$.

The dihydroquercetin reductase activity was strongly inhibited by the product of the reaction, 3,4-cis-leucocyanidin (Figure 9). At a concentration of $0.1 \mathrm{mM}$ in the standard assay, the synthesis of $\left({ }^{14} \mathrm{C}\right) 3,4-c i s$-leucocyanidin was inhibited by approximately $50 \%$. Inhibition was also observed with the 3,4-trans isomer although not to the same extent. A concentration of $0.75 \mathrm{mM}$ was required to obtain $50 \%$ inhibition.

\section{DISCUSSION}

Earlier studies (9) with barley grains showed that $(+)-\left({ }^{14} \mathrm{C}\right)$ dihydroquercetin could be incorporated in vivo into $(+)$-catechin and oligomeric procyanidins, presumably via (+)-2,3-trans $-3,4-$ $c i s$-leucocyanidin. The two initial enzyme activities involved in these conversions have now

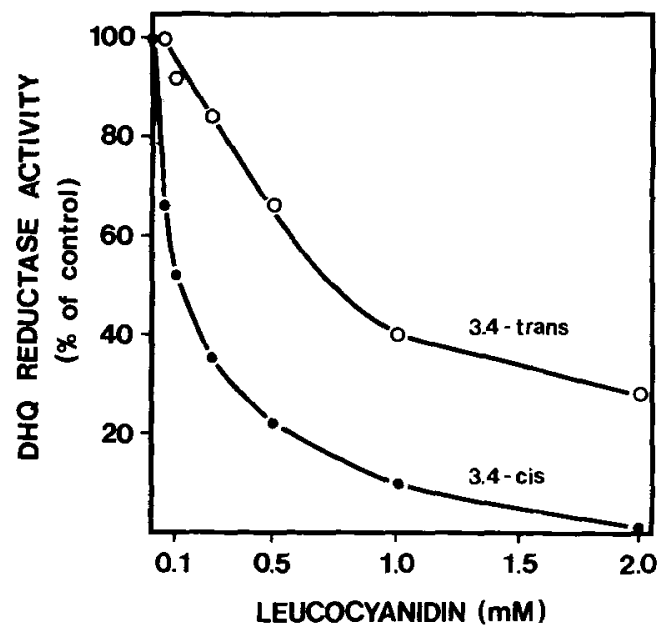

Figure 9. Effect of (+)-2,3-trans-3,4-cis- and (+)-2,3trans-3,4-trans-leucocyanidin on (+)-dihydroquercetin (DHQ) reductase activity. The individual unlabelled leucocyanidins were added to the standard enzyme assay (section 2.6) at the concentrations indicated.

been demonstrated in an enzyme preparation from maturing grains (Figure 10). To obtain these results a $(+)-2,3$-trans-3,4-cis-leucocyanidin standard was required. Therefore, this compound was synthesized and its structure for the first time, directly characterized in the free phenolic form. The reductase activity was strongly inhibited by (+)-2,3-trans-3,4-cis-leucocyanidin and might therefore be subject to feed-back inhibition in vivo. Enzymatic reductions of $(+)$-dihydroflavonols to the corresponding (+)-flavan-3,4-cis-diols, in stereospecific, NADPH-dependent reactions, have also been reported by STAFFORD and co-workers $(12,13$, $14,15)$ in connection with proanthocyanidin biosynthesis in cell cultures of Douglas fir needles, and by HeLLER et al. (7) in connection with anthocyanidin biosynthesis in Matthiola incana. Whereas pH-optima of 7.4 and 6.0 were found for the enzymes involved in proanthocyanidin and anthocyanidin biosynthesis, respectively, the (+)-dihydroquercetin reductase activity from barley grains showed pH-optima at both 7.0 and 6.0 . This intimates the potential presence of two activities, one having a pH-opti- 
<smiles>O=C1c2c(O)cc(O)cc2OC(c2ccc(O)c(O)c2)[C@@H]1O</smiles>

\section{DIHYDROQUERCETIN}<smiles>Oc1cc(O)c2c(c1)O[C@H](c1ccc(O)c(O)c1)[C@H](O)[C@H]2O</smiles>

\section{2,3-trans-3,4- cis - LEUCOCYANIDIN}<smiles>O=S(=O)(O)OC1Oc2cc(O)cc(O)c2C[C@H]1O</smiles>

\section{CATECHIN}

Figure 10. The enzymatic conversion of (t)-dihydroquercetin to (+)-catechin via (+)-2,3-trans-3,4-cis-leucocyanidin.

mum at 7.0 being involved in procyanidin synthesis, and a second having a pH-optimum at 6.0 being involved in cyanidin synthesis. The presence of tissue-specific isoenzymes in the barley grains would not be surprising, since proanthocyanidins are synthesized in the testa layer $(1,2,9)$ whereas anthocyanins are synthesized in the palea-lemma tissue (8). Additional studies of (+)-dihydroquercetin reductase activity in barley grains should lead to a clarification of this question.

Secondly, a NADPH-dependent reductase, capable of converting (+)-2,3-trans-3,4-cis-leucocyanidin to $(+)$-catechin (Figure 10) was dem- onstrated in the barley extract. The maximal activity of this 3,4-cis-leucocyanidin reductase in the enzyme extract was, however, only $1 / 40$ of that obtained for the (+)-dihydroquercetin reductase. An NADPH-dependent (+)-2,3-trans3,4-cis-leucocyanidin reductase has also been demonstrated in enzyme extracts from cell cultures of Douglas fir needles by STAFFORD and co-workers $(13,15)$, either in a double step reduction of $(+)$-dihydroquercetin, or when using the 3,4-cis-leucocyanidin as substrate. (Preliminary experiments using the enzyme extract of barley grains have also shown the conversion of $\left(4-{ }^{3} \mathrm{H}\right)-3,4-c i s-l e u c o c y a n i d i n$ into labelled (+)-catechin).

The postulated (9) condensing enzyme activities, involved in the synthesis of oligomeric procyanidins, i.e., one adding (+)-2,3-trans-3,4cis-leucocyanidin to (+)-catechin to form procyanidin dimer (B3), and a second adding the leucocyanidin to the dimer to form procyanidin trimer $(\mathrm{C} 2)$, were not detected in the present studies. Their identification will be the object of future studies.

\section{ACKNOWLEDGEMENTS}

I am grateful to Dr. P. voN WetTSTEINKNOWLES for reviewing the manuscript, to Drs. F. POULSEN and J. KINDTLER, Dept. of Chemistry, Carisberg Laboratory, for taking the ${ }^{1} \mathrm{H}$ NMR spectrum, to B. PETERSEN for growing the plants, and to N. RASMUSSEN for preparing the figures.

\section{REFERENCES}

1. AASTRUP, S.\&H. OUTTRUP: Location and characterization of barley flavanoids during grain filling. Eur. Brewery Conv., Congr. Proc. Helsinki 1985, 667-674 (1985)

2. Aastrup, S., H. OUtTrup \& K. Erdal: Location of the proanthocyanidins in the barley grain. Carlsberg Res. Commun. 49, 105-109 (1984)

3. Attwood, M. R., B. R. BRown \& W. T. Pike: Epimerisation of 4-acetoxyflavans and of flavan-4ols. J. Chem. Soc. Perkin Trans. I, 2229-2235 (1983)

4. BAIG, M. I.J.W. W.CLARK-LEWIS \& M.J. THOMPSON: Flavan derivatives XXVII. Synthesis of a new racemate of leucocyanidin tetramethyl ether $(2,3$ - 
cis-3,4-trans-isomer): N. M. R. spectra of the four racemates of leucocyanidin tetramethyl ether $\left(5,7,3^{\prime}, 4^{\prime}\right.$-tetramethoxyflavan-3,4-diol). Aust. J. Chem. 22, 2645-2650 (1969)

5. BRADFORD, M. M.: A rapid and sensitive method for the quantitation of microgram quantities of protein utilizing the principle of protein-dye binding. Anal. Biochem. 72, 248-254 (1976)

6. Delcour, J. A., D. Ferreira \& D. G. Roux: Synthesis of condensed tannins. Part 9. The condensation sequence of leucocyanidin with (+)-catechin and with the resultant procyanidins. J. Chem. Soc. Perkin Trans. I, 1711-1717 (1983)

7. Heller, W., G. ForkMANN, L. BritsCh \& H. GRISEBACH: Enzymatic reduction of (+)-dihydroflavonols to flavan-3,4-cis-diols with flower extracts from Matthiola incana and its role in anthocyanin biosynthesis. Planta 165, 284-287 (1985)

8. JENDE-STRID, B.: Mutations affecting flavonoid synthesis in barley. Carlsberg Res. Commun. 43, 265-273 (1978)

9. KRISTIANSEN, K. N.: Biosynthesis of proanthocyanidins in barley: Genetic control of the conversion of dihydroquercetin to catechin and procyanidins. Carlsberg Res. Commun. 49, 503-524(1984)
10. MARKHAM, K. R.: Techniques of flavonoid identification. Academic Press, London (1982)

11. PORTER, L. J. \& L. Y. Foo: Leucocyanidin: Synthesis and properties of $(2 \mathrm{R}, 3 \mathrm{~S}, 4 \mathrm{R})-(+)-$ $3,4,5,7,3^{\prime}, 4^{\prime}$-hexahydroxyflavan. Phytochemistry 21, 2947-2952 (1982)

12. Stafford, H. A \& H. H. Lester: Enzymic and nonenzymic reduction of ( + -dihydroquercetin to its 3,4-diol. Plant Physiol. 70, 695-698 (1982)

13. StafFord, H. A. \& H. H. Lester: Flavan-3-ol biosynthesis. The conversion of (+)-dihydroquercetin and flavan-3,4-cis-diol (leucocyanidin) to $(+)$-catechin by reductases extracted from cell suspension cultures of Douglas fir. Plant Physiol. $76,184-186$ (1984)

14. Stafford, H. A. \& H. H. Lester; Flavan-3-ol biosynthesis. The conversion of (+)-dihydromyricetin to its flavan-3,4-diol (leucodelphinidin) and to $(+)$-gallocatechin by reductases extracted from tissue cultures of Ginkgo biloba and Pseudotsuga menziesii. Plant Physiol. 78, 791 -794 (1985)

15. Stafford, H. A., H. H. Lester \& L. J. Porter: Chemical and enzymatic synthesis of monomeric procyanidins (leucocyanidins or 3',4',5,7-tetrahydroxyflavan-3,4-diols) from (2R,3R)-dihydroquercetin. Phytochemistry 24, 333-338 (1985) 